\title{
PENGARUH EKSTRAK KULIT PETAI (Parkia speciosa) SEBAGAI ANTIOKSIDAN ALAMI PADA PEMAKAIAN MINYAK GORENG DEEP FRYING TERHADAP KADAR MDA HEPAR MENCIT (Mus musculus)
}

\author{
Gusti Ramadani \\ Rumah Sakit Muhammadiyah Lumajang \\ Email: gustiramadani22@yahoo.com
}

\begin{abstract}
ABSTRAK
PENGARUH EKSTRAK KULIT PETAI (Parkia speciosa) SEBAGAI ANTIOKSIDAN ALAMI PADA PEMAKAIAN MINYAK GORENG DEEP FRYING TERHADAP KADAR MDA HEPAR MENCIT (Mus musculus). Latar Belakang: Pemakaian minyak goreng berulang dengan suhu tinggi dapat menimbulkan berbagai masalah kesehatan akibat terbentuknya radikal bebas dan senyawa toksik akibat proses oksidasi. Proses oksidasi dapat dicegah dengan pemberian antioksidan. Kulit petai mempunyai kandungan senyawa fenolik sebagai antioksidan yang kuat.Tujuan: Membuktikan pengaruh pemberian ekstrak kulit petai sebagai antioksidan alami pada pemakaian minyak goreng deep frying terhadap kadar MDA hepar mencit.. Metode: Eksperimental dengan menggunakan rancangan The Post Test Only Control Group Design. Sampel dibagi menjadi 5 kelompok. Kelompok 1 (kontrol negatif), kelompok 2 (kontrol positif) diberi diet minyak goreng deep frying dengan dosis $0,5 \mathrm{ml} / 100 \mathrm{gr} \mathrm{BB} /$ hari selama 7 hari, dan 3 kelompok diberi minyak goreng yang sudah ditambahkan ekstrak kulit petai konsentrasi $200 \mathrm{mg} / \mathrm{L}, 400 \mathrm{mg} / \mathrm{L}, 800 \mathrm{mg} / \mathrm{L}$ dengan dosis masing-masing 0,5 $\mathrm{ml} / 100 \mathrm{gr} \mathrm{BB} /$ hari selama 7 hari. Hasil: Ekstrak kulit petai memberikan pengaruh yang sangat signifikan antar kelompok perlakuan $(\mathrm{P}<0,01)$. Hasil uji Tukey didapatkan notasi yang berbeda antara kontrol positif dengan seluruh kelompok perlakuan,berarti didapatkan pengaruh ekstrak kulit petai terhadap pencegahan kenaikan kadar MDA hepar. Kesimpulan: Pemberian ekstrak kulit petai sebagai antioksidan alami pada pemakaian minyak goreng deep frying dapat mencegah kenaikan kadar MDA hepar mencit.
\end{abstract}

Kata Kunci: Ekstrak kulit petai, Senyawa fenolik, MDA hepar, Minyak goreng deep frying

\begin{abstract}
The Effect of Petai Pods' Extract (Parkia speciosa) as Natural Antioxidant in Deep Frying oil of Hepatic MDA Levels of Mice (Mus musculus). Background: Multiple usage of cooking oil with a high temperature can cause a variety of health problems due to the formation of free radicals and toxic compounds as a result of the oxidative process. The oxidative process can be prevented by giving an antioxidant. Petai pods' consist of phenolic compounds that have a high antioxidant activity.Objective: To prove the effect of petai pods' extract as natural antioxidants on the usage of deep frying cooking oil toward hepatic MDA levels of mice. Methods: The study was experimental with The Post Test Only Control Group Design. The samples were divided into 5 groups. Group 1 (negative control), group 2 (positive control) fed a diet of deep frying cooking oil at a dose of $0.5 \mathrm{ml} / 100 \mathrm{~g}$ body weight / day for 7 days, and the three other groups were given cooking oil that had been added petai pod's extract with concentration of $200 \mathrm{mg} / \mathrm{L}, 400 \mathrm{mg} / \mathrm{L}, 800 \mathrm{mg} /$ $L$ respectively with each dose of $0.5 \mathrm{ml} / 100 \mathrm{~g}$ body weight / day for 7 days. Results and Discussion: Petai pods' extract showed a very significant effect between groups $(P$ <0.01). Meanwhile the result of Tukey test obtained different notations between positive control compare with the rest of the groups. It meant that petai pods' extract showed a prevention effect toward the increasing of hepatic MDA levels. Conclusions: Petai pods' extract as natural antioxidant in deep frying oil could prevent the increasing of hepatic MDA levels.
\end{abstract}

Key word: Petai pods' extract, Phenolic compounds, Hepatic MDA, Deep frying oil

\section{PENDAHULUAN}

Minyak goreng adalah salah satu kebutuhan penting yang diperlukan oleh masyarakat Indonesia. Menurut data Departemen Pertanian RI (2009) konsumsi dan ketersediaan minyak goreng kelapa sawit untuk konsumsi selama periode 2002-2007 cenderung meningkat dengan pertumbuhan sekitar 6,58\% setiap tahunnya dalam hal konsumsi rumah tangga. Menggoreng bahan pangan dengan minyak menjadi metode yang sering digunakan oleh orang Asia untuk mengolah bahan pangan (Adam, 2007). Minyak goreng berasal dari minyak nabati yang telah dimurnikan dan digunakan sebagai penghantar panas, penambah rasa gurih, 
penambah nilai kalori pada bahan pangan yang digoreng, membuat tekstur dan penampakan bahan pangan menjadi lebih menarik, serta permukaan yang kering (Dewi dan Hidajati, 2012). Akan tetapi jika minyak goreng digunakan secara berulang kali akan membahayakan kesehatan (Ghidurus et al, 2010).

Berbagai penelitian telah dilakukan oleh para peneliti yang membuktikan dampak negatif dari minyak goreng yang berulang kali dipakai. Minyak bekas ini lebih dikenal dengan minyak jelantah yang sudah mengalami perubahan pada komposisi kimianya (Rukmini, 2007). Hal tersebut terjadi karena pada saat pemanasan akan terjadi proses destruksi berupa degradasi, oksidasi dan dehidrasi dari minyak goreng. Proses ini dapat meningkatkan kadar peroksida dan pembentukan radikal bebas yang bersifat toksik, sehingga membahayakan bagi tubuh. Akibat serangan radikal bebas maka akan terbentuk produk toksik (Mulyati dan Meilina, 2007; Oktaviani, 2009). Salah satu petanda yang digunakan untuk mengetahui kondisi patologis yang terjadi pada tubuh seseorang adalah malondialdehida (Setijowati, 1998). Untuk mencegah proses pembentukan radikal bebas yang bersifat toksik tersebut, maka perlu ditambahkan antioksidan pada minyak goreng sebelum digunakan dalam proses penggorengan (Ayucitra, 2011).

Antioksidan adalah substansi yang dapat menghambat atau mencegah proses oksidasi pada substrat yang mudah teroksidasi (bahan makanan yang mengandung karbohidrat, protein, dan lemak) jika ditambahkan pada konsentrasi rendah. Berdasarkan sumbernya, antioksidan dapat dibedakan menjadi dua, yaitu antioksidan sintetis dan antioksidan alami. Antioksidan sintetis yang dikenal sebagai antioksidan paling efektif untuk minyak nabati adalah tert-butyl bydroquinon (TBHQ), sedangkan antioksidan alami umumnya diperoleh dari senyawa fenolik atau polifenol tumbuhan yang dapat berupa golongan flavonoid, turunan asam sinamat, tokoferol, dan lain-lain (Ayucitra, 2011).

Antioksidan sintetis lebih sering digunakan sebagai antioksidan minyak goreng karena tergolong murah dan cukup efektif untuk digunakan sebagai antioksidan. Namun dewasa ini pemakaian antioksidan sintetis mulai mendapat respon negatif karena berpotensi menyebabkan kanker dalam tubuh. Di beberapa negara maju, seperti Jepang dan Kanada, penggunaan antioksidan sintetis seperti BHA, BHT, dan TBHQ telah dilarang. Oleh karena itu, penggunaan antioksidan alami sebagai pengganti semakin diminati karena dipercaya lebih aman untuk kesehatan (Iqbal, 2005; Sultana et al., 2007)

Indonesia, sebagai salah satu negara agraris yang kaya akan sumber daya alam, memiliki beragam tumbuhan yang berpotensi besar untuk dimanfaatkan, salah satunya sebagai sumber antioksidan alami. Dari studi literatur menunjukkan bahwa tanaman petai mengandung senyawa fenolik yang berpotensi sebagai antioksidan untuk minyak nabati (Amarnath, 2004). Tanaman petai (Parkia speciosa) tersedia melimpah di Indonesia karena tanaman ini mudah tumbuh di mana saja, akan tetapi kulit petai masih belum banyak dipergunakan dan biasanya dibuang begitu saja sebagai limbah. Oleh karena itu, pemanfaatan kulit petai sebagai sumber antioksidan alami sangat menjanjikan dan perlu untuk diteliti lebih dalam (Ayucitra, 2011). Menurut Fransisco,
(2011), antioksidan pada kulit petai 2 kali lipat dibandingkan dengan buahnya.

\section{METODE}

Penelitian ini merupakan penelitian eksperimental yang digunakan adalah metode The Post Test Only Control Group Design. Merupakan rancangan penelitian dimana hasil penelitian diamati setelah perlakuan selesai.

Penelitian ini akan dilaksanakan selama 1 bulan bertempat di:

1. Ekstraksi dilakukan di Laboratorium Biomedik Fakultas Kedokteran Universitas Muhammadiyah malang

2. Perlakuan hewan coba bertempat di Laboratorium Farmakologi Fakultas Kedokteran Universitas Muhammadiyah Malang

3. Uji kadar MDA (Malondialdebyde) bertempat di Laboratorium Fisiologi Fakultas Kedokteran Universitas Brawijaya

Populasi penelitian ini adalah mencit mus musculus, tidak ada abnormalitas dan dalam kondisi sehat serta ditandai dengan gerakan yang aktif. Kemudian disesuaikan dengan kriteria inklusi yaitu umur 8 minggu, berat badan 25-30 gram, berkelamin jantan dan sehat yang ditandai dengan gerakan yang aktif. Kriteria eksklusinya adalah mencit mati selama penelitian dan tidak mau makan saat perlakuan. Mencit diaklimatisasi dahulu dengan lingkungan dan pakan selama satu minggu di laboratorium diberi makan pellet dan diberi minum air sebelum diberi perlakuan sambil diamati kesehatannya.

Estimasi besar replikasi yang digunakan pada penelitian ini adalah dengan rumus berikut:

$$
\begin{aligned}
& (t-1)(p-1)>15 \\
& (t-1)(5-1)>15 \\
& 4 t-4>15 \\
& 4 t>19 \\
& t \quad>4,75 \\
& t \quad>5
\end{aligned}
$$

(Supranto, 2007).

Ekstrak kulit petai adalah ekstrak berbentuk serbuk yang ditambahkan pada minyak goreng kelapa sawit dengan konsentrasi $200 \mathrm{mg} / \mathrm{L}$ (P1), $400 \mathrm{mg} / \mathrm{L}$ (P2), dan $800 \mathrm{mg} /$ L (P3) yang diektraksi dengan metode maserasi di laboratorium Biomedik Fakultas Kedokteran Universitas Muhammadiyah Malang. Kulit petai dipisahkan dari buahnya. Bahan baku berupa kulit petai terlebih dahulu dipotong kecil kecil (ukuran $1 \mathrm{~mm}$ x $1 \mathrm{~mm}$ ) dan dijadikan serbuk sebelum dipakai dalam proses ekstraksi. Proses ekstraksi dilakukan menggunakan pelarut etanol dengan perbandingan jumlah solid terhadap pelarut adalah 1:10 (b/v) pada kecepatan pengadukan $500 \mathrm{rpm}$ sampai diperoleh yield ekstrak konstan. Larutan filtrate didinginkan lalu disaring dengan kertas Whatman $110 \mathrm{~mm}$. Filtrat dipekatkan dengan vakum oven pada suhu $50^{\circ} \mathrm{C}$ pada tekanan rendah (600 mmHg) hingga diperoleh serbuk ekstrak. 
Untuk mendapatkan hasil penghambatan yang baik, ekstrak kulit petai dapat ditambahkan pada minyak goreng dengan konsentrasi lebih dari $200 \mathrm{mg} / \mathrm{L}$ (Ayucitra, 2011). Untuk mengetahui dosis mana yang paling efektif dalam mencegah kenaikan kadar MDA pada mencit yang dipapar minyak goreng kelapa sawit deep frying digunakan dosis ekstrak kulit petai dengan konsentrasi $200 \mathrm{mg} / \mathrm{l}, 400 \mathrm{mg} / \mathrm{l}$, dan $800 \mathrm{mg} / 1$.

Minyak goreng yang digunakan adalah minyak yang berasal dari tanaman golongan palm yang dapat menghasilkan minyak, yakni kelapa sawit. Sampel yang digunakan dalam penelitian ini adalah minyak goreng curah yang diperoleh dari pasar tradisional. Mula-mula minyak goreng dibagi dalam 4 wadah dengan volume masingmasing 1L kemudian wadah diberi label kelompok II (tanpa penambahan ekstrak kulit petai), kelompok III (penambahan ekstrak kulit petai $200 \mathrm{mg}$ ke dalam $1 \mathrm{~L}$ ), kelompok IV(penambahan ekstrak kulit petai $400 \mathrm{mg}$ ke dalam 1 L) dan kelompok V(penambahan ekstrak kulit petai $800 \mathrm{mg}$ ke dalam $1 \mathrm{~L}$ ). Pencampuran ekstrak ke dalam minyak goreng menggunakan mixer dengan kecepatan 2000 rpm selama 40 menit. Pada masing-masing minyak goreng akan dilakukan simulasi penggorengan singkong 50 gram dengan metode deep frying pada suhu $150-180^{\circ} \mathrm{C}$ selama 15 menit sejumlah 4 kali pengulangan penggorengan.

Mencit yang digunakan sebanyak 25 ekor, terbagi menjadi 5 kelompok dan tiap kelompok terdiri dari 5 ekor mencit.

(1) Kelompok I: Kontrol negatif (tanpa perlakuan)

(2) Kelompok II: Kontrol positif yaitu pemaparan mencit dengan minyak goreng deep frying dengan penggorengan 4 kali.

(3) Kelompok III: Perlakuan 1 yaitu pemaparan mencit dengan minyak goreng kelapa sawit deep frying dengan penggorengan 4 kali secara per-oral yang sebelum melewati proses penggorengan telah ditambahkan ekstrak kulit petai dengan konsentrasi $200 \mathrm{mg} / \mathrm{L}$ (P1).

(4) Kelompok IV: Perlakuan 2 yaitu pemaparan mencit dengan minyak goreng kelapa sawit deep frying dengan penggorengan 4 kali secara per-oral yang sebelum melewati proses penggorengan telah ditambahkan ekstrak kulit petai dengan konsentrasi $400 \mathrm{mg} / \mathrm{L}$ (P2).

(5) Kelompok V: Perlakuan 3 yaitu pemaparan mencit dengan minyak goreng kelapa sawit deep frying dengan penggorengan 4 kali secara per-oral yang sebelum melewati proses penggorengan telah ditambahkan ekstrak kulit petai dengan konsentrasi 800 mg/L (P3).
Kemudian minyak goreng diberikan kepada mencit masing-masing kelompok secara peroral dengan dosis $5 \mathrm{ml} /$ 100gr BB/hari dengan menggunakan sonde modifikasi selama 7 hari.

Pada percobaan hari ke -15 dilakukan dekapitasi terhadap hewan coba. Berat badan hewan coba ditimbang kemudian dilakukan dislokasi leher satu persatu terhadap hewan coba yaitu dengan ekor mencit dipegang dan kemudian ditempatkan pada permukaan yang bisa dijangkaunya. Mencit akan meregangkan badannya. Saat mencit meregangkan badannya, pada tengkuk ditempatkan suatu penahan, misalnya pensil atau batang logam yang dipegang dengan tangan kiri. Ekornya ditarik dengan tangan kanan dengan keras, sehingga lehernya akan terdislokasi dan mencit akan terbunuh. Hewan coba dibunuh secara dislokasi leher. Kemudian dilakukan pengambilan jaringan hepar pada mencit dilakukan perhitungan kadar MDA Hepar. Metode ini berdasarkan prinsip bahwa bila MDA direaksikan dengan TBA (Thiobarbituric Acid) akan membentuk senyawa berwarna merah muda. $100 \mathrm{mg}$ jaringan hepar mencit dihomogenasi lalu ditambahkan $1 \mathrm{ml}$ akuades dan ditampung di ependorf lalu ditambahkan larutan TCA 100\% 100 uL, NaThio 1\% $100 \mathrm{uL}$ dan $\mathrm{HCl} 1 \mathrm{~N} 250 \mathrm{uL}$. Larutan yang sudah dicampurkan dipanaskan dengan suhu $100^{\circ} \mathrm{C}$ selama 20 menit. Setelah dipanaskan dilanjutkan dengan sentrifuse dengan kecepatan 3500 rpm selama 10 menit untuk mendapatkan supernatant.Tambahakan akuades sampai dengan $3500 \mathrm{uL}$ lalu gunakan spektrofotometri untuk mendapatkan nilai absorbansinya. Nilai absorbansi yang didapatkan dimasukkan dalam persamaan: $\mathrm{y}=0,0004 \mathrm{x}-0,0126$ dimana fungsi $\mathrm{y}$ diperankan oleh nilai absorbansinya dan fungsi $\mathrm{x}$ diperankan oleh nilai kadar Malondialdebyde.

Analisis data dengan uji One Way ANOVA untuk membuktikan adanya perbedaan yang bermakna antara kontrol dengan perlakuan terhadap kadar MDA. Uji Tukey 5\% merupakan uji kelanjutan dari uji One Way ANOVA, digunakan untuk mengetahui perbedaan yang bermakna antar kelompok perlakuan dalam penelitian.

\section{HASIL DAN PEMBAHASAN}

Hasil penelitian pengaruh ekstrak kulit petai (Parkia speciosa) sebagai antioksidan alami pada pemakaian minyak goreng deep frying terhadap kadar MDA hepar mencit (Mus musculus) dapat digambarkan pada gambar berikut :

Tabel 1. Distribusi Frekuensi Karakteristik Sampel

\begin{tabular}{|c|c|c|c|c|c|c|c|}
\hline \multirow[t]{2}{*}{ Perlakuan } & \multicolumn{5}{|c|}{ Kadar MDA Hepar (ng/mL) } & \multirow{2}{*}{$\begin{array}{l}\text { Rata - } \\
\text { Rata }\end{array}$} & \multirow{2}{*}{$\begin{array}{l}\text { Standart } \\
\text { Deviasi }\end{array}$} \\
\hline & Sampel 1 & Sampel 2 & $\begin{array}{l}\text { Sampel } \\
3\end{array}$ & Sampel 4 & Sampel 5 & & \\
\hline $\begin{array}{l}\text { Kontrol } \\
\text { negatif }\end{array}$ & 74 & 71,5 & 79 & 71,5 & 71,5 & 73,5 & 3,26 \\
\hline Kontrol positif & 96,5 & 99 & 91,5 & 101,5 & 101,5 & 98 & 4,29 \\
\hline P1 & 79 & 74 & 66,5 & 79 & 71,5 & 74 & 5,30 \\
\hline $\mathbf{P} 2$ & 81,5 & 79 & 76,5 & 74 & 74 & 77 & 3,26 \\
\hline P3 & 74 & 79 & 79 & 71,5 & 79 & 76,5 & 3,53 \\
\hline
\end{tabular}


Tabel 2. Hasil Uji One Way Anova

\begin{tabular}{|c|c|c|c|c|c|}
\hline \multicolumn{6}{|c|}{ ANOVA } \\
\hline KADAR MDA (ng/ & & & & & \\
\hline & $\begin{array}{l}\text { Sum of } \\
\text { Squares }\end{array}$ & df & Mean Square & $\mathrm{F}$ & Sig. \\
\hline Between Groups & 2116.500 & 4 & 529.125 & 33.331 & .000 \\
\hline Within Groups & 317.500 & 20 & 15.875 & & \\
\hline Total & 2434.000 & 24 & & & \\
\hline
\end{tabular}

Tabel 3. Uji HSD Tukey $5 \%$

\begin{tabular}{llllll} 
& K Negatif & K Positif & P1 & P2 & P3 \\
K Negatif & & $*$ & - & - & - \\
K Positif & $*$ & & $*$ & - & - \\
P1 & - & $*$ & & - & - \\
P2 & - & $*$ & - & - & \\
P3 & - & $*$ & - & & \\
\hline
\end{tabular}

Berdasarkan tabel 1 di atas terlihat bahwa terjadi ratarata kenaikan kadar MDA hepar paling tinggi pada kelompok kontrol positif dengan nilai kadar $98 \mathrm{ng} / \mathrm{mL}$ dan kadar MDA hepar terendah pada kelompok kontrol negatif dengan nilai kadar MDA hepar 73,5 ng/mL. Berdasarkan uji normalitas (uji Shapiro-Wilk $\mathrm{p}>0,05$ ) dan homogenitas (uji Levene $\mathrm{p}>0,05)$ menunjukkan bahwa semua data berdistribusi normal dan homogen. Selanjutnya dapat disimpulkan bahwa kadar MDA hepar mencit dapat dilanjutkan dengan uji One Way Annova. Berdasarkan hasil uji One way ANOVA pada tabel 2 menunjukkan bahwa terdapat perbedaan kadar MDA hepar pada tiap kelompok (Sig 0,000).

Berdasarkan hasil uji HSD Tukey 5\% antara kelompok negatif dengan kelompok P1, P2 dan P3 kadar MDA hepar yang tidak berbeda signifikan ( $\mathrm{Sig}=0,641)$ namun kelompokkelompok ini berbeda signifikan apabila dibandingkan dengan kelompok kontrol positif (Keterangan: tanda * bermakna bahwa ada perbedaan yang signifikan antara kelompok yang dibandingkan).

Berdasarkan hasil penelitian dan analisis data menunjukkan bahwa pemberian ekstrak kulit petai pada pemakaian minyak goreng deep frying dapat mencegah kenaikan kadar MDA hepar mencit (Mus musculus). Pada kelompok kontrol negatif (K-) didapatkan rata-rata kadar MDA 73,5 ng/mL. Pada kelompok kontrol positif $(\mathrm{K}+)$ yang diberi diet minyak goreng deep frying $4 \mathrm{x}$ penggorengan secara per oral didapatkan kadar MDA hepar yang lebih tinggi jika dibandingkan dengan kelompok Kontrol negatif (K-). Hal ini sejalan dengan penelitian Oeij (2007) yang menyatakan bahwa terdapat hubungan antara jumlah penggorengan minyak goreng dengan kenaikan kadar MDA hepar dimana semakin banyak jumlah penggorengan akan meningkatkan kadar MDA.

Pada hasil uji Oneway ANOVA menunjukkan adanya perbedaan kadar MDA hepar antar kelompok mencit. Pada kelompok P1, P2 dan P3 menunjukkan kadar MDA hepar mencit yang lebih rendah dibandingkan kontrol positif. Pada kelompok P1 didapatkan kadar MDA hepar yang paling mendekati kelompok kontrol negatif. Rendahnya kadar MDA hepar mencit pada kelompok P1, P2 dan P3 diduga karena penambahan ekstrak kulit petai dalam penggunaan minyak goreng deep frying yang mengandung senyawa antioksidan yakni senyawa fenolik dan polifenol tannin yang berperan menghambat proses oksidasi minyak goreng yang dipanaskan dengan suhu tinggi. Dengan penambahan antioksidan tersebut proses pembentukan radikal bebas hidroperoksida dapat dicegah sehingga kadar hidroperoksida dalam minyak goreng dapat diminimalkan yang dibuktikan dengan penurunan peroxide value (PV) (Ayucitra, 2011)

Pada kelompok P2 dan P3 didapatkan kadar MDA hepar yang lebih tinggi bila dibandingkan dengan kontrol negatif dan kelompok P1.Tingginya kadar MDA hepar pada kelompok P2 dan P3 diduga akibat efek toksik dari senyawa fenol. Menurut Bull (2007), dosis fenol yang tinggi (12-40 $\mathrm{mg} / \mathrm{kg} /$ hari) yang dipaparkan pada tikus secara oral per sonde sudah bisa menyebabkan nekrosis pada organ ginjal, hepar dan timus. Penyebab lain dari tingginya kadar MDA hepar ini diduga akibat stress fisik pada kelompok P2 maupun P3 sehingga meningkatkan radikal bebas. Hal ini sejalan dengan yang disampaikan oleh Yuniastuti (2008). Beberapa mencit pada kelompok P2 dan P3 mengalami perlukaan akibat berkelahi satu sama lain. Luka-luka pada mencit yang berkelahi diduga berpengaruh terhadap tingginya kadar MDA mencit. Hal ini sesuai dengan pendapat Lobo et al (2010) bahwa peningkatan radikal bebas ini juga bisa disebabkan oleh adanya proses inflamasi seperti yang terjadi pada mencit kelompok P2 dan P3. Namun pada uji Tukey $5 \%$ bisa dijelaskan bahwa perbedaan kadar MDA diantara kelompok P1, P2 dan P3 tidaklah signikan.

Hasil penelitian ini mendukung teori bahwa senyawa fenolik dan polifenol pada kulit petai dapat berperan sebagai antioksidan alami pada pemakaian minyak goreng deep frying. Hal ini ditunjukkan dengan lebih rendahnya kadar MDA hepar mencit (Mus musculus) pada kelompok P1, P2 dan P3 jika dibandingkan dengan kadar MDA hepar pada kelompok 
yang diberi diet minyak goreng deep frying tanpa diberi ekstrak kulit petai (kontrol positif). Namun penggunaan antioksidan perlu diperhatikan dosisnya, karena penggunaan berlebihan dapat menimbulkan efek pro-oksidan.

Keterbatasan penelitian ini adalah tidak bisa didapatkan konsentrasi paling efektif untuk mencegah kenaikan kadar MDA hepar karena terdapat data yang tidak linier. Data yang tidak linier ini akibat adanya kadar P2 yang lebih tinggi jika dibandingkan dengan kelompok P1 dan P3. Sehingga pada penelitian selanjutnya perlu dilakukan penelitian dengan konsentrasi ekstrak yang lebih rendah dari $200 \mathrm{mg} / \mathrm{L}$ dalam minyak goreng dan perlu dilakukan uji kualitas minyak untuk mengetahui ekstrak kulit petai terhadap minyak goreng.

Secara keseluruhan dari hasil penelitian ini diketahui bahwa diet minyak goreng deep frying per oral dapat meningkatkan kadar MDA hepar mencit dan penambahan ekstrak kulit petai (Parkia speciosa) pada minyak goreng deep frying sebelum proses penggorengan dapat mencegah kenaikan kadar MDA hepar mencit secara signifikan. Pada penelitian ini hipotesis yang diajukan tidak sepenuhnya terbukti. Ekstrak kulit petai (Parkia speciosa) sebagai antioksidan alami dapat mencegah kenaikan kadar MDA hepar mencit (Mus musculus) pada konsentrasi ekstrak kulit petai $200 \mathrm{mg} / \mathrm{L}$ sedangkan pada konsentrasi ekstrak 400 $\mathrm{mg} / \mathrm{L}$ dan $800 \mathrm{mg} / \mathrm{L}$ kadar MDA hepar mencit cenderung meningkat.

\section{SIMPULAN}

Berdasarkan hasil dan pembahasan dalam penelitian ini dapat ditarik kesimpulan sebagai berikut :

1. Kadar MDA (Malondialdebyde) hepar mencit yang diberi minyak goreng deep frying per oral lebih tinggi daripada kelompok mencit yang tidak diberi minyak goreng deep frying $(p=0,000)$.

2. Pemberian ekstrak kulit petai (Parkia speciosa) sebagai antioksidan alami pada pemakaian minyak goreng deep frying dapat mencegah kenaikan kadar MDA hepar mencit (Mus musculus).

3. Kadar MDA (Malondialdebyde) hepar mencit mengalami kenaikan pada konsentrasi ekstrak 400mg/L dan $800 \mathrm{mg} / \mathrm{L}$ diduga akibat efek toksik senyawa fenolik pada ekstrak kulit petai

\section{DAFTAR PUSTAKA}

Adam, S.K.,Sulaiman, N.A., Top, A.G., Jaarin, K. 2007. Heating reduces vitamin $E$ content in palm and soy oils. Malaysian Journal of Biochemistry and Molecular Biology;15(2):76-79.

Aisha, A.F., Abu-Salah, K.M.,Alrokayan, S.A et al. 2012. Evaluation of antiangiogenic and antioxidant properties of Parkia speciosa Hassk extracts. Pak J Pharm Sci. 25(1):714.

Andarwulan, N.,Faradilla, R.F. 2012. Senyawa Fenolik Pada Beberapa Sayuran Indigenous dari Indonesia. Seafast Center. Institut Pertanian Bogor.Hal:1.

Amarnath, B. 2004. A Study on Antioxidant Nature of Petai. Tesis. Degree of Master Science Department of Chemistry National University of Singapore.
Arief, S. 2009 . Radikal Bebas. Bagian Ilmu Kesehatan Anak Fakultas Kedokteran Universitas Airlangga/RSU Dr. Soetomo. Publication.http:// wmw.kalbe.co.id/files/ cdk/files/10RadikalBebas102.pdf/10 RadikalBebas102.html. 16 Oktober 2012.

Atmosukarto, K dan Rahmawati, M. 2003. Mencegah Penyakit Degeneratif dengan Makanan.Cermin Dunia Kedokteran 140: 41-48.

Ayucitra, A.,Indraswati, N.,Mulyandasari, V dkk. 2011. Potensi Senyawa Fenolik Bahan Alam Sebagai Antioksidan Alami Minyak Goreng Nabati .Widya Teknik Vol. 10, No. 1, 2011 (1-10).

Azeredo, H.M.C.,Faria J.A.F., Silva. 2004. Minimization of proxide formation rate in soybean oil by antioxidant combinations. Food Research International 37: 689-94.

Badan Standardisasi Nasional. 2012. Minyak Goreng Sawit. Vol: SNI 7709:2012. Hal 1-2. Jakarta.

Bull, S. 2007. Phenol Toxicological Overview. Health Protection Agency Version 2. Hal: 9.

Edem, D.O. 2002.Palm oil: biochemical, physiological, nutritional, hematological, and toxicological aspects: a review. Plant Foods for Human Nutrition: 57(3-4):319-341.

Castillo'n, P.G.,Artalejo F.R.,Fornés N.S et al. 2007. Intake of fried foods is associated with obesity in the cohort of Spanish adults from the European Prospective Investigation into Cancer and Nutrition. Am J Clin Nutr 2007; 86:198 205.

Chevion, S., Moran DS, Heled Y et al. 2003. Plasma antioxidant status and cell injury after severe physical exercise. Proc.Nati.Acad.Sci.USA, vol. 100, Issue 9, pp. 51195123.

Current Protocols. 2010. Measurement of a MalondialdebydeDNA Adduct.http://www.currentprotocols.com/ protocol/tx0302. (28 Agustus 2013).

Dalimunthe, N.A. 2009. Pemanfaatan Minyak Goreng Bekas Menjadi Sabun Mandi Padat. Tidak dipublikasikan, Tesis, Sekolah Pascasarjana Universitas Sumatera Utara.Hal:12.

Departemen Pertanian RI. 2009. Analisis Konsumsi Pangan. Pusat Data dan Informasi Pertanian. Jakarta. Hal: 68.

Dewi, M. T. I. dan Hidajati, N. 2012. Peningkatan Mutu Minyak Goreng Curah Menggunakan Adsorben Bentonit Teraktivasi. UNESA Journal of Chemistry, 1: 47-53.

Dorfman, S. E., Laurent, D., Gounarides, J.S et al. 2009. Metabolic Implications of Dietary Trans-fatty Acids. Obesity vol.17 no. 6:1200-1207. Publication. mnn.nature. com/oby/journal/v17/n6/full/oby2008662a.btml. 23 Oktober 2012.

Drake, R.L, Vogl W and Mitchell A.W.M .2007. Gray's anatomy for students, Elsevier, New York.

Droge, W .2002. Free radical in the physiological control of cell function. Physiol Rev, no. 82, pp. 47-95.

Erbinova, E., Kagan V., Han D et al. 1991. Free radical recycling and intramembrane mobility in the antioxidant properties of alpha-tocopherol and alpha-tocotrienol. Free Radical Biology and Medicine: 10(5):263-275.

Eroschenko, V.P. 2003. Atlas histologi di fiore dengan korelasi fungsional, Edisi 9, Penerbit Buku Kedokteran EGC, Jakarta. 
Fajarwati, E. 2001. Pengaruh Rumput Laut (Euchema spinosum) Terhadap Aktivitas Radikal Bebas pada Hepar Tikus (Rattus novergicus) yang Mendapat Diet Kolesterol Tinggi, Fakultas Kedokteran Universitas Brawijaya Malang.

Febriansyah, R. 2007. Mempelajari Pengaruh Penggunaan Berulang dan Aplikasi Adsorben Terhadap Kualitas Minyak dan Tingkat Penyerapan Minyak Padadan Kacang Salut. Skripsi. Fakultas Teknologi Pertanian:Institut Pertanian Bogor.

Francisco, G.,Setyo A.D. 2011. Pemanfaatan Kulit Petai Sebagai Antioksidan Alami untuk Minyak Goreng Kelapa Sawit. Skripsi. Sarjana, Universitas Katolik Widya Mandala Surabaya.

Ghidurus, M.,Turtoi M.,Boskou G et al. 2010. Nutritional and bealth aspects related to frying. Romanian Biotechnological Letters: Vol. 15, no 6.

Graaff, V.D. 2001. Human anatomy. $6^{\text {th }}$ ed. Mc Graw-Hill. London.

Guyton, A.C and Hall J.E. 2008, 'Liver as an organ', in Guyton AC \& Hall JE (eds.), Textbook of medical physiology, 11th edn, Elsevier, Singapore.

Halliwell, B., Whiteman, M.2004. Measuring reactive species and oxidative damage in vivo and in cell culture: how should you do it and what do the results mean?.Br. J. Pharmacol. 142, 231-255.

Hancock. 1999. Lipid peroxidation-DNA Damage by Malondialdebyde. <http://www.ncbi. nlm.nih.gov/ entrez/query.fegy? cmd+Retrieve\&db=Pub Med\&list_ uids $=100648522 \&$ dopt $=$ Abstract $>$.

Herawati, S. 2006. Kinerja (Bht) sebagai antioksidan minyak sawit pada perlindungan terhadap oksidasi oksigen singlet. Akta Kimindo 2: 1-8.

Hernani, Raharjo, M. 2005. Tanaman berkhasiat Antioksidan, Penebar Swadya, Jakarta.

Iqbal, S and Anwar, F. 2005. Antioxidant Properties and Components of Some Comercially Available Varieties of Rice Bran in Pakistan. Hal: 265-272.

Jusup, S.A., Raharjo, S.S. 2010. Efek Ekstrak Daun Krokot (Portulaca oleracea L.) Sebagai Anti Oksidan Alami Terhadap Kadar Alanin Transaminase (ALT) dan Gambaran Histologi Sel Hepar Rattus norvegicus L. yang Diberi Minyak Goreng deep frying.Skripsi.Surakarta. Universitas Sebelas Maret.

Kamisah, Y,Othman, F.,Qodriyah, H.M.S et al. 2013. Parkia speciosa Hassk.: A Potential Phytomedicine. Hindawi Publishing

Corporation Evidence-Based Complementary and Alternative Medicine. Volume 2013, Article ID 709028.

Ketaren. 1986. Pengantar Teknologi Minyak dan Lemak Pangan, Penerbit Universitas Indonesia, Jakarta.

Ketaren, S. 2008. Minyak dan Lemak Pangan. Penerbit Universitas Indonesia. Jakarta.

Kontos, HA. 2001. Oxygen radicals in cerebral ischemia: the stroke willis lecture, no.32, pp. 2712-2716.

Kowalski, B., Ratusz, K., Kowalska, D et al.2004. Determination of The Oxidative Stability of Vegetable Oils by Differential Scanning Calorimetry and Rancimat Measurements, J. Lipid Sci. Techno., Vol. 106.

Kumalaningsih, S. 2007. Antioksidan Alami.Surabaya: Trubus Agrisarana.
Larsen, W.J .2002. Anatomy: development, function \& clinical correlations, $9^{\text {th }}$ Ed. Saunders, Philadelphia.

Lee, J.,Lee, S., Lee, H et al. 2002. Spinach (Spinacia oleracea) as a natural food grade antioxidant in deep fat fried products. J. Agric. Food Chem 50: 5664-9.

Lestari, P.P. 2010. Pemanfaatan Minyak Goreng Jelantah Pada Pembuatan Sabun Cuci Piring.Tesis.Universitas Sumatera Utara. Medan

Lobo, V., Patil, A.,Phatak, A et al. 2010. Free Radicals, Antioxidants and Functional Foods: Impact on Human Health. Phrmacognosy Review.Publication.http:// www.ncbi.nlm.nib.gov/pmc/articles/PMC3249911/ ?report=classic. 7 Februari 2013

Lopes, G.K.,Schulman, H.M.,Lima, M.H. 1999. Polyphenol tannic acid inbibits bydroxyl radical formation from Fenton Reaction by Complexing Ferrous Ion. Biochimica et Biophysica Acta 1472. Hal 142-152.

Mahardhika, C. 2013. Fraksionasi Ekstrak Kulit Petai Berpotensi Antioksidan.Skripsi.Departemen Kimia Fakultas Matematika dan Ilmu Pengetahuan Alam Institut Pertanian Bogor.

Malhi, H., Gores, G. J. 2008. Molecular Mechanism of Lipotoxicity in Nonalcoholic Fatty Liver Disease. Semin Liver Dis., 28(4):360-369.

Materiamedica. 2013. Keterangan Determinasi Tanaman Petai. Dinas Kesehatan Provinsi Jawa Timur UPT Materia Medica. Batu.

Muchtadi, T.R.,Sugiyono.,Ayustaningwarno. 2011. Ilmu Pengetahuan Bahan Pangan. Alfabeta. 265-282.

Mulyati, S., Meilina, H. 2007 . Pemurnian Minyak Jelantah denganMenggunakan Sari Mengkudu. Publication.bttp://222.124. 186.229/gdl40/ go.php?id=gdlnode-gdl-res-2007-srimulyati1082\&node=351 \&start $=6.16$ Oktober 2012.

Naz, S.,Siddiqi,R.,Sheikh, $\mathrm{H}$ et al. $2005 . \quad$ Deterioration of Olive, Corn and Soybean Oils Due to Air, Light, Heat and Deep-Frying. Food Res. Int. 38, 127-134.

Nogala-Kalucka, M, Korczak, J.,Elmada et al. 2005. Effect of $\dot{a}$ - and $\ddot{a}$-Tocopherol on the Oxidative Stability of a Mixed Hydrogenated Fats Under Frying Conditions. Eur. Food Res. Technol. 221, 291-297.

Oktaviani, N.D. 2009. Hubungan lamanya pemanasan dengan kerusakan minyak goreng curah ditinjau dari bilangan peroksida. Jurnal Biomedika. 1:31-4.

Perwitasari, D.S. 2009. Penambahan Kunyit sebagai Antioksidan Alami pada Minyak Goreng Curah. Jurnal Kimia dan Teknologi 8 ISSN 0216 - 163 X. FakultasTeknologi Industri UPN Veteran.

Rahmantina. 2010. Pengaruh Pemberian Vitamin C terhadap Kadar MDA Serum pada Lansia, Majalah Kedokteran Andalas 29 (2).

Rohdiana, D. 2001. Aktivitas Daya Tangkap Radikal Polifenol Dalam Daun Teh, Majalah Jurnal Indonesia $12,(1), 53-58$.

Roshetko, J. M., Wiyono, S. R., Prastowo, N. H. 2008. Evaluating Indigenous Practices for Petai (Parkia speciosa Hassk.) Seed Germination: The Effect of Seed Shelling and Seed Cutting on Germination, Growth, and Survival. Smallscale Forestry, Vol. 7, Hlm. 285-293.

Rukmini, A. 2007. Regenerasi Minyak Goreng Bekas dengan 
Arang Sekam Menekan Kerusakan Organ Tubuh. Seminar Nasional Teknologi 2007 (SNT 2007). ISSN: 1978 - 9777.

Sartika, R.A.D. 2009. Pengaruh Suhu dan Lama Proses Menggoreng (deep frying) terhadap Pembentukam Asam Lemak Trans. Markara Sains. Vol 13. 23-28.

Setijowati, N. 1998. Pengaruh Radikal Bebas dan Vitamin E terhadap Jumlah Circulating Endhotel pada Darah Tikus yang Dipapar Asap Rokok Kretek Secara Kronik. Majalah Kedokteran Unibraw, (XIV) 3: 94-99.

Shahidi, F. 2005. Bailey's Industrial Oils and Fat Products, $6^{\text {th }}$ Ed, John Wiley and Sons Inc. Publication, New York.

Shanker, G.,Syverson, T.,Aschner, J.L et al. 2005. Modulatory Effect of Glutatbione Status and Antioxidants on Methylmercury-induced Free Radicals Formation in Primary Cultures of Cerebral Astrocytes. Brain Res. Mol. Brain Res, no. 37, pp. 11-22.

Silalahi, J. 2006. Antioksidan dalam Diet dan Karsinogenesis. Cermin Dunia Kedokteran. 153. hal 42-47.

Siswonoto, S .2008. Hubungan kadar malondialdehid plasma dengan keluaran klinis stroke iskemik akut. Tesis . Program Pasca Sarjana Magister Ilmu Biomedik dan Program Pendidikan Dokter Spesialis Ilmu Penyakit Saraf, Universitas Diponegoro, Semarang.

Specialchem.2013.Publication.http://www. specialchem 4adhesives.com/tc/antioxidants/index.aspx?id =degradation. 29 Oktober 2013

Sultana, B.,Anwar, F., and Przybylski, R.2007. Antioxidant Potential of Corncob Extracts for Stabilization of Corn Oil Subjected To Microwave Heating. Food Chemistry, Vol. 104, No. 3, Hal. 997-1005.

Supranto, J. 2007. Teknik Sampling Survey \& Eksperimen. PT Rineka. Jakarta.

Tahir, I.,Wijaya, K.,Widianingsih, D. 2003. Seminar on Chemometrics- Chemistry Dept Gadjah Mada University, Terapan Analisis Hansch Untuk Aktivitas Antioksidan senyawa Turunan Flavon/Flavonol.

Oeij.,Adhika A.,Atmadja, W.L.,Achmad, S.,Tohardi, A. 2007. Gambaran Anatomi Mikroskopik dan Kadar Malondialdehida pada Hati Mencit setelah pemberian Minyak Kelapa Sawit Bekas Menggoreng. JKM.Vol. 7. 15-25.

Tunsaringkarn.,Soogarun, S.,Rungsiyothin, A et al. 2012. Inbibitory activity of Heinz body induction in vitro antioxidant model and tannin concentration of Thai mimosaceous plant extracts, Journal of Medicinal Plants Research, vol.6, no. 24, pp. 4096-4101.

Widayat, S dan Haryani, K. 2006. Optimasi Proses Adsorbsi Minyak Goreng Bekas Dengan Adsorbent Zeolit alam: Studi Pengurangan Bilangan Asam. Jurnal Teknik Gelagar, 17, 77 - 82 .

William, C. 2013. James Hutton Institute (and Mylnefield Lipid Analysis), Invergowrie, Dundee (DD2 5DA), Scotland. Publication. http:/ / lipidlibrary.aocs.org/Lipids/ tocol/ index.htm. 17 Oktober 2013

Winarno FG. 1999. Minyak Goreng dalam Menu Masyarakat. Jakarta: Balai Pustaka,

Winarno, F.G. 2002. Kimia Pangan dan Gizi. Jakarta.PT Gramedia Pustaka Utama.

Winarsi, H. 2007. Antioksidan Alami dan Radikal Bebas, Kanisius, Yogyakarta, hal.80.
Yoshikawa, T and Naito, Y. 2002. Oxidative stress, What Is Oxidative Stress?. Journal of the Japan Medical Association 45(7): 271-276.

Yuniastuti, A. 2008. Gizi dan Kesehatan. Graha Ilmu. Yoyakarta.

Yustinah dan Hartini. 2011 . Adsorbsi Minyak Goreng Bekas Menggunakan Arang Aktif dari Sabut Kelapa. Prosiding Seminar Nasional Teknik Kimia "Kejuangan" Yogyakarta. ISSN 1693 - 4393. Universitas Muhammadiyah Jakarta. Hal: 1.

Xian, T.K.,Omar, N.A.,Ying, L.W et al. 2012. Reheated Palm Oil Consumption and Risk of Atherosclerosis: Evidence at Ultrastructural Level.Evid Based Complement Alterante Med 2012. Publication.http:// wmw.ncbi.nlm.nih.gov/pmc/articles/ PMC3541024/. 20 September 2013.

Zainuri, M dan Wanandi, S.I. 2012. Aktivitas spesifik manganese superoxide dismutase (MnSOD) dan katalase pada hati

tikus yang diinduksi hipoksia sistemik: hubungannya dengan kerusakan oksidatif', Media Litbang Kesehatan, vol. 22, no. 2 . 